\title{
Art in the Service of Religion: A Study of Selected Carvers of Ifa Sculptures and Objects in South-Western Nigeria
}

\author{
Sanda Francis Ademola ${ }^{1}$, Oladokun Taiwo Olaniyi ${ }^{2, *}$ \\ ${ }^{1}$ Department of Curriculum and Teaching, University of Calabar, Calabar, Nigeria \\ ${ }^{2}$ Centrefor Black and African Civilization, Abuja, Nigeria
}

Email address:

afrodemmy@yahoo.com (O. T. Olaniyi)

${ }^{*}$ Corresponding author

\section{To cite this article:}

Sanda Francis Ademola, Oladokun Taiwo Olaniyi. Art in the Service of Religion: A Study of Selected Carvers of Ifa Sculptures and Objects in South-Western Nigeria. International Journal of Architecture, Arts and Applications. Vol. 3, No. 4, 2017, pp. 53-62.

doi: $10.11648 /$ j.ijaaa.20170304.12

Received: November 11, 2016; Accepted: April 21, 2017; Published: June 16, 2017

\begin{abstract}
Significant works have been done on the religious content, uniqueness and functionality of African art and objects. However, not much has been done on carvers of religious sculptures. This paper therefore provides a fresh historical account on the origin and exponents of wood carving in Oyo Southwestern Nigeria. Two prominent families of traditional religious wood carvers in Oyo were studied: the Oke family of Ebike clan and the Odekunle family. A comparative analysis of the works of the two families was carried out to determine the historical timeline, stylistic and thematic features of their cult wood carving, especially (Ifa cult) in Oyo. Findings revealed the wide margin of variation in the works of the two most prominent carver families in Oyo. Other issues bewildering the survival religious wood carving tradition and traditional art in general in the Nigeria were articulated and suggestions were proffered.
\end{abstract}

Keywords: Art, Ifa, Religion, Sculpture

\section{Introduction}

The functionality of African Art to African religions has, for a long time, been a subject of academic inquiry. In fact, the concept of art for art sake is alien to the traditional African artist whose creations are taken from and devoted to the soul of the community. In other words, the African artist creates objects for specific social needs. This does not imply that the artist always creates for free, but the primary objective is never pecuniary. This position is amplified by a view on the value of art in Africa, quoted in Yudelman (1964) which states that the African in general has no desire to produce more than he needs for subsistence level and that putting silver in his pocket is not the African's first aim and objective.

This disposition of the artist to creativity becomes stronger where his religion is involved. This is because Africans are known to be essentially religious and they attach spiritual importance to every facet of life. Therefore, their artists are inspired more by religious beliefs than by reasons of aesthetics. Thus, in Africa, it is possible to encounter religious motifs even in decorative art works.

Steiner (1994); Willet (1993); Brain (1980); Parrot (1972) and Wescott (1958) have all established the uniqueness and functionality of African art and objects. Their findings also revealed that religion is integral to creativity. The foregoing does not only strengthen the position that traditional African art is essentially religious, it also places sculpture at the heart of belief and worship. In other words sculpture is used to entrench traditional religious beliefs and enhance the process of worship.

However, while significant works have been done on the religious content and spiritual functionality of African art, not much has been done on carvers of religious sculptures. This was also observed by Parrot when he said that the strength or energy or power evoked by the use of the (art) object in a ritual or a ceremony was considered more important than the object itself or the person who fashioned the object. Furthermore, the identity of the traditional African artist is rarely known, perhaps because once he had created the object, he, as individual artist became unimportant. The essence of this paper therefore is to direct scholarly attention to carvers or fashioners of religious sculptures and religious 
art in general with the view to providing insights into their world; enhance the understanding of their practice; the functionality of their works and the general understanding of traditional African religious art.

\section{Traditional African Sculpture: Nature and Functionality}

As earlier mentioned, academic discourse on the mystical and supernatural concepts that influence African Art has been approached in different ways. Awoonor contends that discussion of art, mask, carvings, sculptures and their functions in the traditional African society must be based on a broad philosophical system that is capable of establishing a rational pattern of thought, so as to illuminate the acclaimed interrelationship and interdependence between things (Material and mater) and spirit (gods and deities). [9]

The "Polytheism/Monotheism" construct of Yoruba religion as described by Idowu offers the best philosophical approach in this regard. The belief in Olodumare as the Supreme Being who controls the universe is termed monotheism while the worship of the latter through His many ministers (divinities) is described polytheism. These divinities are, consequently, concretized in diverse forms, using different visual mediums such as wood, stone, metal and other organic materials to bridge the gap between the mortal and the divine. [32] This idea of iconography therefore constitutes African religious sculpture tradition. Rothens New Encyclopedia of Art [37] also stresses the reality of spirit world and gods as outstanding factors of African arts. Gillon recalls the rock art of the Sahara which recoded mythological symbols and rituals designed to overcome danger, invoke fertilities and combat threats of the supernatural.

African sculpture varies in size and style depending on the part of the continent from where such sculptures evolved. For instance, in West Africa, figures with long bodies, square shape and idealized physiognomy are common while disc shaped head adorned with circular dots and shapes can be found in Central Africa, among the people of Gabon. East Africa is known for caryatid and support for entablature made of shortish human form. The various sizes and styles of African sculpture exemplify the diversity of ethnicity that make African continent.

Religious sculptures in Nigeria: an overview

Production of religious sculptures in largest number among African society has for long been credited to Nigeria. Willet recorded William Fagg's visit to Nigeria where he confirmed the country's rich sculpture tradition [40].Nigerian sculptures, as in other African societies, function to edify life and service the social system. An exhibition of Ancient Tones and Columns form the Eastern part of Nigeria by the Visual Art Association of Nigeria (VASON) and the National Gallery of Art in 2008 is a proof. The show flaunted large pieces of wooden male and maternity figures and ancestors' Column of various sizes in quite a reasonable number. Objects of ritual worship, over life size statue of ancestor spirit usually found in the darkened Shrine and ancient ritual drums with profusely carved human form from Urhobo land were on display. Cole's study on Nigerian ethnic art also analyzed various intersections of art and ritual with regular socio-religious undertones [12]. South Western Nigeria, home to the Yoruba, is noted for its rich sculpture tradition, a position supported by Drewal who stated that in the arts, the Yoruba are heirs to one of the oldest and finest artistic traditions in Africa, a tradition that remains vital and influential today. [18] The old Oyo Empire, comprising Benin was renowned for court arts while other towns in the empire such as Ile Ife (now in Osun State) and Owo (now in Ondo State) have a rich history of Yoruba art that is rooted in the traditional belief systems.

\section{Ifa Belief and Worship in Nigeria}

The history, practice, process and instruments of divination across cultures have attracted a sizable number of studies. While some focused on the process of Ifa divination system of the Yoruba, others examined the entire divination concept as it cuts across cultures. For example, Abimbola focused on the significant position occupied by Ifa divination in Yoruba religious belief [1]. He has written extensively on the oral tradition as the source of historical evidence through which Ifa divination prose, poetry and mythology was established. Another study of such nature is Ezio Basani (1994), Manuel Jurdan, and Permberton. (2007) these scholars have also contributed immensely to the knowledge of Yoruba Ifa divination process. George and Thompson in their own contribution conducted a survey of traditional religious practices in Ibadan. The study reveals the existence and adherence to Ifa divination system even with the prevalence of Christianity. [22] Their study also focused on the process of divination. Idowu's study which sees Ifa (Orumila) as one of the principal ministers of Olodumare (God) is another point of reference. [23]

Ifa connotes the Yoruba approach to divination through the verses of literary corpus called Odu. In the Yoruba religious myth, Ifa, one of about four hundred divinities worshipped by the Yoruba people is the only one whom tradition holds in highest esteem. Bascom (1969) and Awolalu (1979).Ajayi[4] confirmed that most of the various forms of divination among the Yoruba are off-shoots of Ifa divination and that no matter what other divinity a man worships, he/she still seeks knowledge of Ifa in times of trouble.

This analysis justifies Ajayi's description of Ifa as:

The body of knowledge and system of social, emotional and pathological control, employing relevant historical and mythological precedents contained in the special divinatory verses to be recited, chanted or song by the Babalawo (Ifa priest). [4]

Bascom puts it clearer by maintaining that of all the methods of divination employed by the Yoruba, Ifa is regarded as the most important and the most reliable [10]

Ifa divination process entails the solemn sitting position of the priest and the supplicant opposite each other. The 
divination tray is placed between them as the source of revelation and a platform where Odu symbols related to the supplicant's quest are impressed. The client is then offered a cowry shell (Ibo) to which his problem is whispered, he drops the shell on the tray afterwards for the Babalawo (the Priest) to interpret, having deeply understood Ifa corpus (OduIfa) which is a vast body of literary prose and poetry that encapsulates the experiences and wisdom of Yoruba. The Babalawo then narrates the verses that are relevant to the client's situation. He then casts the sacred palm kernel nuts eight times, at the end of which inference is drawn for necessary prescription and solution to the supplicant's problem.

\section{Ifasculpturesin Nigeria}

In spite of the philosophy of conservatism that structures Ifa divination system, the intrinsic cultural divergencesamong Yoruba States informs the widespread of variations in the carving of Ifa sculptures albeit, with some commonstylistic tendencies. In other words, carvers of Ifa sculptures are found in all parts of Yoruba land but they can be traced more to areas where Ifa worship is most prevalent.

Studies have also been carried out on the form and content of Ifa sculptures. One of such studies was done by Pogoson and Akande (2011) who study OponIfa (Divination Trays) from Isale Oyo, Oyo.Witte (1994) and Pogoson and Akande indicated that divination trays from Ijebu have a part of the face of Esu extending slightly into the centre of the tray, and that the trays from Osogbo have the face of esu contained within the borders of the tray. This may indicate a stylistic and cultural affinity between both places and Oyo.

Pogoson also reviewed Bassani (1994) who discussed a rarely found divination tray with a Circular but embedded in the rectangular shape. [32] This board was said to have been owned by a German merchant, Christopher Weickmann, in the middle of the 17 th century. Interestingly also, the shape can be said to be two in one. This is one of the most representative trays ever seen.

Other studies relating to Yoruba Ifa sculpture is Drewal (1983), Henry, Margret, Drewal (1987) who explained the serial and seriate compositional pattern on divination tray. The serial compositional arrangement according to this study identifies the images on the tray as unit designs each of which has individual interpretation different from others. The seriate otherwise refers to the myriads of complexities that constitute Yoruba idea of the cosmos as it affects the diviners and their clients.

Drewal divides Opon tray into two major sections. The centers section where the Odu symbols relating to the supplicant is impressed and the border section which further splits into eight sections. The OjuOpon (face of the board) depicting the face of Esu is the most constant and important and the EseOpon (the foot of the tray) directly downward the former. When an imaginary diameter is placed horizontally across the two sections, we have on the right hand side Olumunlotun (the right path), while on the left hand, Olukaranlosi (direct path), within each of these lies the remaining four sections. [19]

Sanda also traces the rationale behind the constant shape of Ifa divination sculptures and finds that the two major shapes of OponIfa; (square and circular) is a means of identifying the two major Ifa cults;AwoElegan (Elegan cult)and Olodu cult (AwoOlodu). In other words, while the circular board is peculiar to Olodu cult, the square board is used by Elegan cult. [35]

Oponifa is one of the most important objects of divination. It is a flat wooden board circular or square depending of the type of Ifa cults to which the owner belongs. Ifa tray (OponIfa) has a recessed plain center where IyereOsun (divination powder) is spread for marking related Odu marks. The slightly high relief border carries the Esu figure on the uppermost center and series of other figures that most times signify Yoruba myths and philosophy.

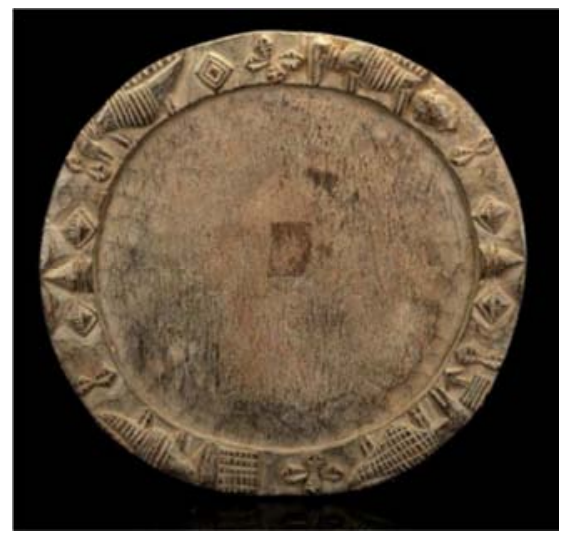

Figure 1. Yoruba Opon Ifa (Circular Divination Tray - Opon Ribiti), Nigeria http://www.imodara.com/item/nigeria-yoruba-opon-ifa-divination-tray/.

Iroke (Divining tapper) is another essential sculptural objects used in Ifa divination. Iroke (tapper) is long, slim, curve and point-ended with a wider opening on the lower end inside which a pendulum is affixed so that when shaken, it produces constant sound. It ranges between twenty and sixty centimeters in length. During divination, the priest continually shakes the Iroke to produce a particular constant sound which is believed to invoke the spirit of Orunmila (the divinity of divination).

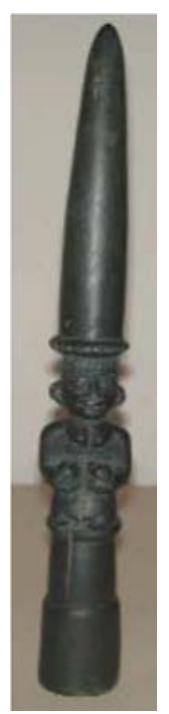

Figure 2. IrokeIfa retrieved from Hearst Museum of Anthropology. 
Ajeere Ifa is a wooden figure a holding a container with lid inside which Ikin-the sacred sixteen palm kernel nuts are kept. According to Abiodun Ajeere can be regarded as a mini earthly temple of Orunmila for the fact that it houses Ikin (the sacred palm kernel nut). He also applauds Yoruba carvers' proficient manipulation of wood as an artistic medium which is evident in the naturalistic rendition of Ajeere Ifa. Oyo carvers most time choose to depict Ajeere Ifa as a kneeling stylized figure. Figures of other poses such as sacrifice bearer, dancing figures among others are also common in other Yoruba communities.

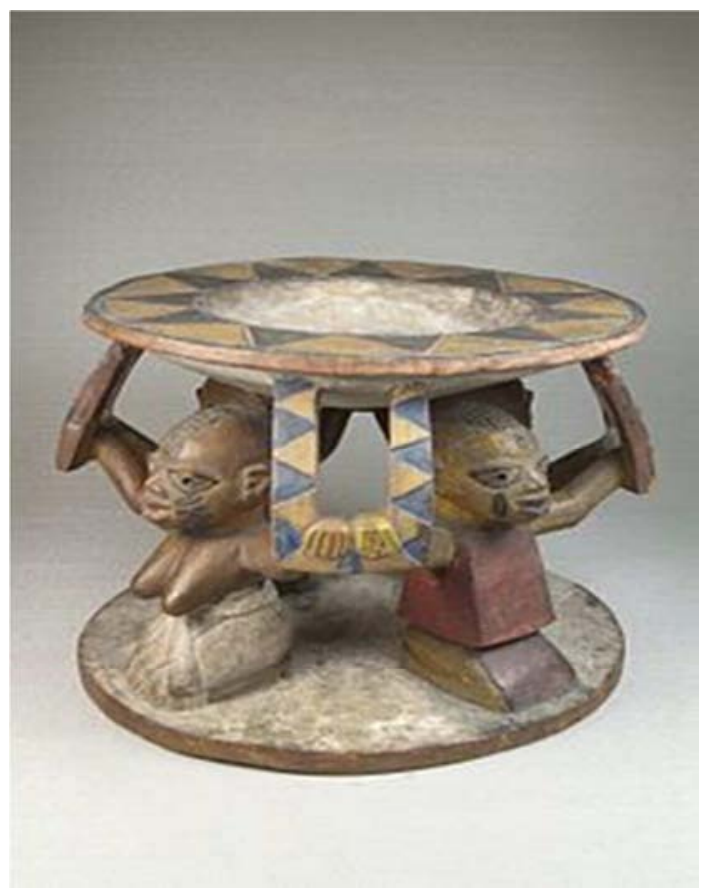

Figure 3. Carved dish for palm nuts (Agere Ifa) in the permanent collection of the Brooklyn Museum.

Ese drums: Ese drum is more of spiritual than sociocultural significance in Oyo Ifa cult, especially with its shape and appearance that is different from other Yoruba drums such as Dun-dun, Bata, e.t.c. Ese drums comes in a set of three usually attached together with strings of leather called (Osan). The three attached drums are carved in circular shape, with hollow and openings at the two ends, having the upper opening covered with leather and profuse leather strings. Carving of Ese drums most times carry embellishment figure relating to sacrificing figures, Ifa festival and other figures that constitute Yoruba aesthetic and visual culture. [35] Among other wooden objects often found in Ifa cult are Igba Odu, a closed box or calabash containing diviner's emblems given to him at initiation and Apoti Ifa, a wooden box with central compartment and four peripheral compartments for storing ritual materials.

\section{Carvers of Ifa Sculptures}

"To discuss a work of art to the exclusion of the life or intent of the artist appears to concur with "Greenbergian formalism". Clement Greenberg, a modern art theorist, as quoted by Layiwola believes that art has its own internal logic and can be understood without making reference to the artist.It also agrees with the nature of Yoruba religious art appreciation culture which tends to consign to obscurity, the maker of the art objects in preference for the art itself. [25]

Religious cult artists especially (Ifa) sculptorshave, for long, been at the disadvantage of the philosophy of conservatism which consigns the production of religious sculptures to rigid conventionalities and places the carver of Ifa sculptures under the shadow of their own products. This was also observed by Brain when he referred to African traditional artists as being craftsmen rather than artists. [11]

The interpretation of this culture is that applaud and appreciation are also often directed at sculptures and not the individual traditional carver. In order to fill this gap, this paper is looking at two prominent families of traditional religious wood carvers in Oyo, Southwestern Nigeria who, through lengthy years of generational transference of carving culture have contributed to historical richness of Yoruba wood carving tradition in Oyo.

Functionality of Ifa sculptures in Nigeria

Art, especially sculpture, to Yoruba people service certain philosophical and ethno-cultural constructs which are targeted towards morality and social cohesion. The Yoruba concept of aesthetic as analyzed by Abiodunencompasses both the inner beauty (intrinsic value) and outer physical value.

In this respect, the major functional values of Ifa art objects lie in its quality of enhancing a successful divination session.It is therefore of paramount priority for carvers of Ifa objects to consider this crucial religious assignments in their selection of material and execution of the objects as not all wood types can be effectively put to use for carving objects of divination.

Ontological significance of Ifa sculpture is also noteworthy. Ifa divination itself with its vast corpus constitutes Yoruba idea of existentialism, therefore Ifa objects help to express in visual terms, the three dimensional representations of myths, philosophies and ideas that are embedded in Yoruba Ifa divination system. For instance the Yoruba concept of OriInu (inner head), fate, or destiny can be visualized and be taught with the combination of the uppermost and middle segments of (Iroke Ifa) divination tapper which Abiodun described as reminiscence of the traditional Yoruba myth which deals with the solemn and sacred period of choosing Ori from Ajala (the great sculptor of Ori from heaven).

The divination board also gives a pragmatic consideration of Yoruba idea of the four cardinal points of the space. The Yoruba belief in the division of the space into four equal parts of east, west, south and north is more of spiritual rather than geographical connotation. [3] This can be portrayed on the imaginary bisectional division of OponIfa into Ojuopon (East), Ese Opon (West), Olumulotun (North), Olukanranlosi (South) and Aarin Opon, Ita Orun (the central point of the tray) which represents the neutral center of the cosmos. Each 
of which is of ritual significance to the priest. Permbeton's study on Opon Ifa also relates the entire complexities of human experience to the relieved clustered part of the divination tray with the circular shape of the board forming the cosmos. [31]

Ifa objects also have aesthetic value which defines the aesthetic tastes and visual culture of the Yoruba people.One of the components of Yoruba aesthetic is OjuOna (artistic sensibility), the visual cognition that enables an artist select and process images form daily experiences into schemata or templates and stored in the memory to be retrieved and modified when necessary. This is evident in carved Ifa objects especially AgeereIfa which is always proficiently rendered with Yoruba artistic style without any preparatory sketches.

The socio-political function of divination sculptures cannot be ignored. For example Iroke functions to demystify the personality of the priest as the learned individual and the representative of Orunmila on earth. This makes Ifa priest to command respect in the society especially when consulted for solution to entangled issues. Among other functions are the core and primary religious functions of each of the objects during divination session which will be discussed later in the study.

\section{Patronage of Traditional Religious Objects}

Collection and patronage of Yorba religious sculptures split into three categories. The first is the primary end users who directly commission the carvers to fashion objects of shrine and ritual practices to fulfill their sense of devotion. The trainees of priests also commission crude effigies as the training stages proceed so as to get prepared before being fully initiated. There are also clients, who out of gratitude to the priests, perhaps, after a successful experience commission the carvers to make the objects. These categories of commissioners are connected to the cult and the primary users of the objects. There is therefore, a cordial relationship between the carvers and these three set of adherents.

Another category of patrons is foreign tourists and art collectors who purchase the works either out of curiosity or for purely aesthetic purposes. Patronage also comes from devotees of Ifa in the Africa in Diasporas as found in places such as Cuba, Brazil, the United States and the Caribbean. We also discovered in the course of this study that carvers of religious sculptures still enjoy royal patronage as confirmed by Bola Odekunle (45), one of our respondents.

\section{Origin of Wood Carving in Oyo}

\footnotetext{
"Boniresebakoti o fingbamo, eyi to ti fin silekoniparunlailai".

This Yoruba adage eulogizes some individuals' undeniable achievements and contributions to the development of genealogical history, especially as it relates to indigenous
}

occupations in Yoruba societies. If history would not be distorted, some personalities would admittedly, continue to occupy the pride of praise. Moreover, the origin of human societies also traces to certain peoples' land-marking achievements.

The history and practice of traditional religious wood carving in Oyo features prominently Ebuke carvers' clan. In fact, it is well known to all and sundry, that provenance of wood carving in Oyo traces to Ebuke Compound of OkeAafin Area in Oyo. Therefore, attempt to discuss traditional wood carving to the exclusion of Ebike carvers would definitely result in a distortion and history devoid of social coherence. Ebike compound is located at Oke Aafin area, Oyo (Southwestern Nigeria) and comprises of carver families who have inherited wood carving from their ancestors and whose descendants till date still practice wood carving as a generational occupation albeit, at lower pace in the recent time. Mr Olayinka Oke, the focus subject and one of the correspondents of this study revealed that, Ebike carver families have continued to enjoy the royal endorsement of successive kings (Alaafins) of Oyo, owing to their consistency and reputation as the most prolific carvers since the reign of the Old Oyo Empire.

Assuming such a reputation couldn't have been a happenstance, the emergence of Ebike clan as prominent traditional carver families in Oyo can be traced to their long established relationship with the successive kings (Alaafin) of Oyo. If Mr Muda's account is anything to go by, the reign of Ebike carvers is closely associated with the complexities that constitute the rise and fall of the Old Oyo Empire. (The fifteen to nineteen century most politically powerful Yoruba State).Ebike carvers were Loyal to the traditional ruler (Alafin) during Oyo's several migrations and settlements at almost seven different locations before finally settling at Oyo Ile and later the present Oyo Akesan. During this period, Ebike carvers migrated together with the king and were saddled with the carving of the palace doors, door posts, panels and other objects that adorn the king's palace at different settlements; religious and royal paraphernalia of the king; varieties of other utilities such as plates, spoon, mortar and pestle and other wooden embellishment sculptures for the kings and the royal household.

There are available historical accounts that coincide with this claim. Aremu (2011) traced genealogy of Are Lagbayi (the Legendary Yoruba wood carver) to the Old Oyo Kingdom and gave a possible suggestion that all Yoruba carvers hail from the Old Oyo Kingdom. In the same connection, Kalilu's (1992) study on the history and art of Yoruba also reviewed the abandonment of the Capital city (Oyo Ile) and the dispersal of the inhabitants with their treasures looted by some vassal kings. He averred that Old Oyo is the key to the understanding of the Arts of West Afica. These accounts among many of such, perhaps substantiate Ebike carvers' claim to have long established a close relationship with the successive kings (Alaafin) of Oyo from the old Oyo Kingdom.

Unlike the other Yoruba (Southwestern Nigeria) court 
artists; Benin and Ife, whose direction of creativity was dictated by the royal families, Ebike carvers, though closely associated with the palace, enjoy more artistic freedom. Royal administrations in Oyo from the old Oyo kingdom thus recognize the Ebike carvers as Oyo court artists through conferment of hereditary chieftaincy title; (Ona-Ebike) and a permanent official residence in the palace. According to the present Onibike of Ona-Ebike, Chief Amusa Ogunbode, there have been as many Ona-Ebike Chiefs as there have been Alafins.

Beyond the royal household, Ebike Carvers edify the religious and social system of the town (Oyo) as the production of many wooden masks, divinity figures, wands and statuettes traces to them. The researcher's visits to Chief Taiwo Abimbola's house (an Ifa priest-son of the renowned academician, Professor Wande Abimbola), where Alias Wasiu Agbegilere of Ebike family was met amidst a heap of Ifa bowls and Esu figures, is pointer to this fact. On other countless occasions, many masquerade-worshiping families and cults adherents in Oyo have had to commission Ebike carvers. Mr Olayinka Oke (65); also provided several instances of trade fairs, exhibitions and traditional art competitions where Ebike carvings were dubbed the best. An example of such exhibition was the second Black and African Festival of Art and Culture FESTAC" 77, during which, according to Olayinka, Late Oke Akanbi his Father's figure was dubbed the best and won the first prize. This claim was although refuted by Mr Bola Odekunle; another interviewed carver who also claimed his father actually won the same prize. Olayinka Oke also mentioned the recently held commemorative exhibition of Oranyan Festival which was organized by the Alafin of Oyo to Celebrate Oduduwa; the acclaimed ancestor of the entire Yoruba race. This exhibition held at Oyo palace and converged in large number, traditional art and Craft of various genres from virtually all Nigerian southwestern states. Ebuke carvers were also reported to have pulled their weight by having the largest collection of archival artifacts. From the fore going, it is deducible that Carving to Ebuke descendants is not a matter of choice, but rather of natural integration. It is this background that produced Olayinkaoke; our case study. Olayiwola Oke (65) having benefitted greatly from the inspiration of his carvefather grew with imbued carving skill. With no much formal education, he had his host of admires and commissioners at teenage and has since been in the practice of religious carving till date.

Another carver lineage of repute in Oyo is Odekunle Family of Agbegilere compound, Jabata Area, Oyo. The Odekunle carvers were said to have originated from OshiEkiti several centuries ago. They first settled down at Oopo Area of Ibadan (the capital City of the present day Oyo State) from where many of them, dispersed to different part of Yoruba land. Late $\mathrm{Pa}$ Odekunle and some members of Odekunle carvers in 1952 came through and settled down in Oyo. Although he is late, Pa Emmanuel Odekunle impacted immensely the Yoruba wood carving tradition in Oyo. During his lifetime he single-handedly carved countless religious artifacts that could not be entirely sold out, despite consistent patronage, even years after his death. Anyone who visits his museum-like studio in Oyo may likely conclude that, till today, late $\mathrm{Pa}$ Emmanuel Odekunle still owns the largest collection of religious artifacts in Oyo.

Beyond his wood carving background in Ibadan, Emmanuel Odekunle was apprenticed to Bamidele Areogun; another researched Yoruba wood carver between 1943 and 1951 in Oye-Ekiti. This afforded him the opportunity of being a product of 1964s Oye Ekiti experimental workshop which produced several other neo-traditional carvers in the likes the high esteemed Lamidi Fakeye, Festus Idehen, and Felix Idubor among others. Emmaunel Odekunle returned to Ibadan after his tutelage in 1951 and in 1952 moved to Oyo town, where he finally settled down and established his first studio to begin his career as a wood carver. His parental background in Yoruba traditional wood carving from his childhood days in Ibadan; his eight years tutelage under Bamidele Aare Ogun in Oye-Ekiti and his participation at Oye Ekiti Experimental Workshop cemented his proficiency in Yoruba carving culture.

Before his death in 2008, he had succeeded in carving a niche for himself in the Yoruba wood carving practice, especially in Oyo. He had also trained a number of prolific carvers including six of his former master; Bamidele Are Ogun's children and his nine biological sons, among several others. One of them, Mr Bola; an accomplished carver and one of our primary sources, also recalled his father's several awards and prices while at the peak of his career between the $70 \mathrm{~s}$ and $80 \mathrm{~s}$. Until old age prevented him from handling carving tools, he was committed to the occupation. Bola and his eight carver brothers have also on different occasions, participated in several local and international exhibitions and have represented government, both local and state at different trade fairs and exhibitions.

\subsection{Comparative Analysis}

In spite of their contemporaneous emergence, and existence within the same historical milieu, the two families selected for this study exhibit divergent artistic skills and styles, as well as similarities in both their works and religious dispositions. These similarities and dissimilarities are thus expatiated below.

\subsection{Categorization}

The first and all-encompassing difference between the two carvers is that of categorization. Odekunle was a neotraditional carver; the category of artists that found a new context for traditional art in the contemporary society, in a bid to prevent it from going into extinction and maximize its economic value. Oke Olayinka on the other hand belongs to the deep-rooted indigenous craftsman category that got naturally integrated into the art of wood carving and followed the pace till date, in spite of confrontation with modernism. This category of artists has for long occupied an obscure role in the society and their works are often given recognition at 
the expense of the makers.

\subsection{Stylistic and Thematic Perspective}

Odekunle's Ifa objects are more of naturalistic and appear polished in rendition. Aside his shrine and smaller alter pieces; Odekunle's figural and non-figural works are mostly large in size and conceptual in form. Many of his secular works express Yoruba folklores and tales which are closely attached to Yoruba religion, such themes as Odu (Ifa Festival) Irubo (Sacrifice), Ihuye Coronation) among others. On the other hand, Chief Oke takes more into consideration, the religious function of his sculptures than the aesthetic value. His works are therefore rather simplistic in nature, without much attention to schematic and naturalistic rendition.

Another noteworthy point is the transposition of Yoruba carving style employing Christian religious themes. Odekunle slightly deviated from entirely Yoruba cult carvings as a result of his exposure to Oye-Ekiti experimental workshop of 1964 where Reverend Father Kelvin Carol introduced him to carving Christian themes, using African style. He produced several Christian religious themes such as Madonna Crucifix, and other catholic alter pieces. Oke on the other hand strictly adheres to carving Yoruba traditional cult objects and other objects of secular utility such as pestle and mortar, Opon Ayo, stool among other mundane objects.

\subsection{Carving Tools}

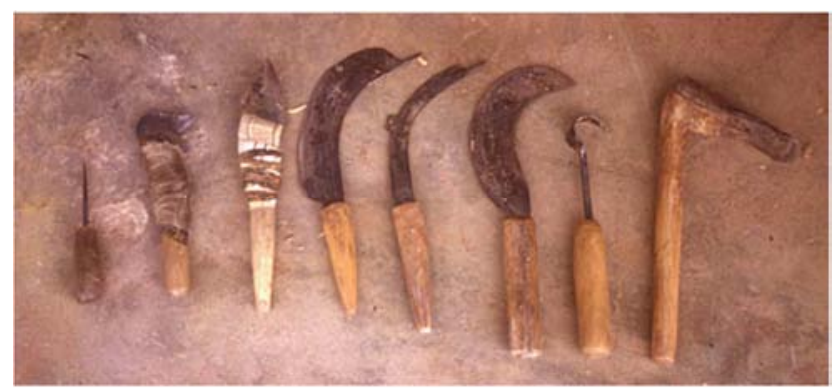

Figure 4. A set of indigenous carving tools used by Ebike carvers.

The traditional art of Nigeria (and many African societies) are characterized by markedly different stylistic traditions and different media. Ebike carvers employ a set of indigenously improvised carving tools of different types, sizes and shapes, each of which serve different functions to the carver. They often buy from Oke Aafin blacksmiths who produce large craft market near the Palace. For instance, a locally fashioned adze called Edun, mostly bought from blacksmiths is used to fell trees. There is another flat-headed type called Ahan which is used to hack trees into portable logs while Omoorin; a flat curve-shaped metal piece is used in chipping woods into shapes. Alupe functions to hollow when dept is needed. Iso is the name accorded to the smallest tool used for detailing forms and finally, Obe Ona; another flat knife is used for carving out detailed symbols, patterns and other necessary finishing touches. Odekunle on the other hand employs the mixture of locally sourced and modern tools such as adze, chisel, hammer, gauges and Rasp file in varying sizes and shapes; this perhaps is informed by his tutelage under Bamidele Are Ogun and experience at the Oye Ekiti Experimental Workshop where Western ideology slipped into afro-traditionalism.

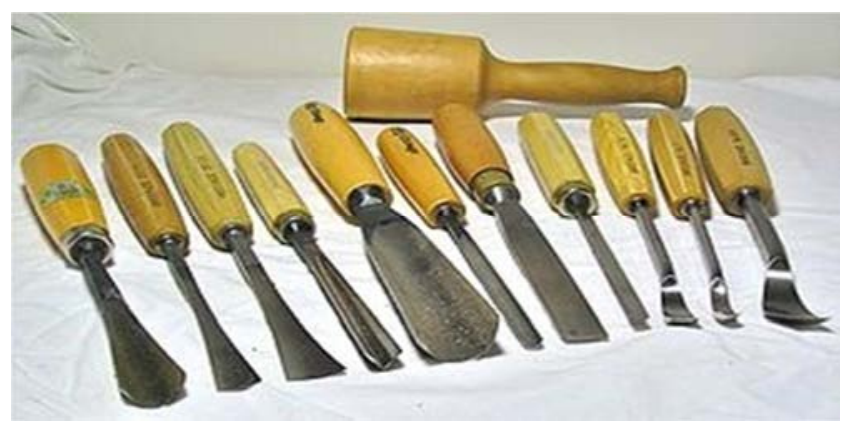

Figure 5. A set of modern carving tools (gauges)fondly used by Odekunle carvers.

\subsection{Schemata and Symbols}

Another area of dissimilarity between the two families is their use of patterns and symbols. Symbols as means of expressing social values has for long been employed by African artists, especially Yoruba. Oyo gourd carvers and leather embroiderers; Iseyin hand woven-textile artists, Abeokuta textile designers among other Yoruba societies, all have peculiar schema to express Yoruba cultural affinity. However, within these schematic commonalities, there exist varying degrees and manners of divergences, owing partly to different intrinsic social cultural value among Yoruba states and partly to the individualistic nature of art. The same reflects on the two carvers' works. More than Oke does, Odekunle, perhaps due to the modern tools used, employs more profuse use of lineal pattern on his works especially AjeereIfa.

\subsection{Patronage}

In the time past, patronage to Yoruba carvers flowed from two major sources; the royal personalities (Kings and Chiefs) were their major patrons, though not necessary in exchange for pecuniary, but mostly prestige, land apportion, and a sense of communal obligation. Following the collapse of the court art, major patronage tilted towards the Yoruba religious adherents which continue till date.It was against this background that Oke carver family emerged. Odekunle's patronage cuts through the Yoruba cults, royal personalities, host of secular admirers and particularly, the European clientele owing to his modern tendencies. The researcher finds that within a short session of interview with Mr Bola Odekunle; one of the eldest carver sons of late Pa Emmanuel Odekunle, more than five collectors from Lagos and other parts of Nigeria approached the gallery. This is a different case on the other end.

\subsection{Similarities}

As earlier maintained, religion and attachment to the soul 
of the community provides a common ground for the practice of wood carving in African societies. However, it is necessary to also consider other commonalities that existed and still exist between both the carver families.

\subsection{Apprenticeship Training System}

As in many other African societies where the practice of wood carving is prevalent, the popular apprenticeship training system is common to the two prominent Oyo carver families. Odekunle's tutelage under Bamidele Areogun and Oke's early exposure to carving from his carver father is a pointer to this fact. Odekunle's exposure to Oye Ekiti experimental workshop in 1964 greatly influenced his work, but with unflinching adherence to Africanism.

Derivation from the same religio-cultural credence of the artists within the same cultural background also informs certain common stylistic tendencies in their works, such as the interwoven lineal motif that is commonly found on Oyo gourd carving and leather embroidery. The use of zoomorphic and anthropomorphic schemata on their divination sculptures is also a point of convergence. This is due to the vantage position animals occupy in Ifa corpus. Ifa adherent-clientele thus demands for animals associated with their destiny to be employed as embellishment forms on their divination sculptures.

\subsection{Religion}

Most Yoruba traditional wood carvers like Oke family and Odekunle have in common traditional religious belief that is informed by the nature of their work. Although the present day carvers have disengaged from traditional religious practice owing to prevalence of Christianity and Islam, there still exists a somewhat cordiality or strong bond between the carvers of Ifa objects and Ifa religion adherents likewise other Yoruba cults. As a result of being shrouded with this phenomenon, traditional worshippers constitute majority of their patrons

Discussion of Findings

This study gives a fresh perspective on the history of wood carving in Oyo. Two indigenous carver families were selected for the study. Findings reveal a wide margin of difference, first in their class of categorization. Odekunle family belongs to the category of a neo-traditional carver while Oke Olayinka whose traditional carving style remained uninfluenced, in spite of confrontation with modernism. There are also divergences in their stylistic and thematic perspectives, while Odekunles' Ifa objects are more of naturalistic and appear polished in rendition, Chief Oke's religious inclination to carvings makes his objects appear crude, and without much attention to schematic and naturalism. Noteworthy is the transposition of Christian religious themes into Yoruba carving culture. Odekunle's tutorship under Reverend Father Kelvin Carol during the 1964 Oye-Ekiti experimental workshop was a major influence. He carved many biblical characters and themes. Chief Oke and his Ebike counterparts on the other hand adhere to carving Yoruba traditional cult objects and other objects of secular utility. The use of tools also makes the difference. While Ebike carvers employ a set of indigenously improvised carving tools, Odekunle employs the mixture of locally sourced and modern tools such as adze, chisel, hammer, gauges and Rasp file in varying sizes and shapes. Their use of Schemata and symbols also make difference. More than Oke does, Odekunle, perhaps due to the modern tools used, employs profuse use of lineal pattern on his works especially Ajeere Ifa. In the same vein, Oke carver family emerged from the background of purely religious obligation and so their patronage flow more from traditional religious adherents while Odekunle's patronage cuts through the Yoruba cults, royal personalities, host of secular admirers and particularly, the European clientele owing to his modern tendencies.

In spite of their many differences however, similarities abound that draw attention to their emergence from the same socio-cultural milieu. First, their religious disposition as it influences their carving culture is a common ground here, the apprentice training system and the natural absorbance into the practice, all form the common ground. Such commonality reflects in their use of interwoven lineal motif that is commonly found on Oyo gourd carving and leather embroidery, it also reflects on the use of zoomorphic and anthropomorphic schemata on their divination sculptures

\subsection{The Future of Religious Sculptures: Suggestions}

Basically, the future of religious sculptures depends on the future of traditional religions. The influence of Christianity and Islam remains strong and pervasive in Oyo town for instance, though Ifa worship is still noticeable. This has also affected the production of Ifa sculptures. But the international dimensions to the religion as well as efforts to sustain it in parts of South Western Nigeria also remain strong. This will sustain the practice of carving religious sculptures, the efficacy of the objects and their preservation.

A favorable and more equitable religious policy in Nigeria will also help the future of Ifa sculptures. At the moment, the Nigerian Constitution guarantees freedom of worship but only Christianity and Islam are accorded official recognition. A constitution review that looks into account the importance of traditional religions will enhance their practice in all ramifications.

More scholarly work should also be done on carvers of religious arts in South Western Nigeria and other parts of the country. This will add to existing literature on religious art and document the styles and dexterity of these sculptors. Private galleries and relevant Government agencies also have roles to play, by Influencing favorable policies and budgetary allocation that can accommodate periodic exhibitions at all level of government. International organizations have been of help in the recent years. For instance, the selection of eighty six traditions across the world tagged as oral and intangible heritage of humanity by (UNESCO) which included the Ifa divination system is a case in point. This has strengthened the preservation of Ifa divination system. It is hoped that such 
attention will soon be given to tangible artistic objects such as the Yoruba Religious Sculpture tradition.

\section{Conclusion}

This paper has discussed the need to revamp the fast degenerating Yoruba wood carving tradition by deconstructing the culture of conservatism that consigns traditional caver to obscurity. It also brings to the fore, a fresh historical account on the origin and exponents of wood carving in Oyo Southwestern Nigeria. In all, two prominent families of traditional religious wood carvers in Oyo were studied. One of them, the Oke family, still enjoys royal patronage of the kings (Alaafins) and has therefore continued to maintain its status as court artists. The other lineage of carvers of Ifa Sculptures is the Odekunle family, used in this study as a variant to determine the historical timeline, stylistic and thematic features of cult wood carvings especially (Ifa cult) in Oyo. A comparative analysis of the works of the two families was carried out and findings revealed the wide margin of variation in their carvings. The paper also remarked severally on the awkward dimension of creativity among the present day traditional wood carvers, resulting from the pervasive prevalence of Islam and Christianity and its reciprocal eclipse of Yoruba religion. It is also significant that the fall in the practice of wood carving does not entirely hinge on the emergence of modernism but also on the inability of the African artists to strike balance. Descendants of the renowned family carvers thus merely live on the past glory instead of having a substantial successive plan for the handed-down wood carving legacy. Like the dance to an unheard tune, present day traditional carvers' withdrawal is also traceable to disparaging local patronage and unfavorable government's policy to patronage from foreign collectors. Other issues bothering on religious wood carving and traditional art in general were expatiated and suggestions were proffered.

\section{References}

[1] Abimbola, W. (1973). The Literature of the Ifa Cult. In Biobaku, S.O. Sources of Yoruba History. Oxford University Press.

[2] Abimbola, W. (1976). Ifa: An Exposition of Ifa Literary Corpus. Ibadan. Oxford University Press.

[3] Abosede, E. (2000). OdunIfa. Nigeria: West African Book Publishers Limited. Lagos Nigeria.

[4] Ajayi, Bade. (1996). Ifa Divination Process: an essay in honor of Professor Wande Abimbola. In Research in Yoruba Language and Literature.

[5] Retrieved www.Universityofilorin.edu.ng/Ajayi/ifaproccess.doc

from

[6] Adepegba, K. (2010) Contemporary Woodcarving: Lagos. Aramoda Creation.

[7] Aremu, G. B. (2001). Are Lagbayi: The Legendary Wood
Carver Chieftain of Old Oyo. In Pogoson, O. I., \&Akande, A. O. (2011). Ifa Divination Tray from Isale Oyo: retrieved from www.cea.revues.org

[8] Awolalu. J.O. (1979) Yoruba Beliefs and Sacrificial Rites. London. Long man Group Ltd.

[9] Awoonor, Kofi. (1975). A Survey of the History, Culture and Literature of Africa South of Sahara. New York: Anchor Press/ Doubleday, Garden city.

[10] Bascom, W. (1969). Ifa Divination: Communication Between God and Men in West Africa. Bloomington and London: Indiana University Press.

[11] Brian, R. (1980) Art and Society in Africa. London and USA. Longman.

[12] Cole, H. (1970) African Arts of Transformation. Santa Barbara, CA. University of California Press.

[13] Drewal, H. J (2009). The Splendour of Ancient Ife. Art in an Early West African State. In Drewal H. J and Schildkrout Enid (Kingdom of Ife. Sculptures from West Africa. London. The British Museum Press.

[14] Drewal, H. J., Pemberton III, and Abiodun, R. (1991). Yoruba Art and Aesthetics. Zurich. Rietberg Museum.

[15] Drewal, H. J., \& Pemberton III, J. (1994), The Yoruba Artist: New Theoretical Perspectives on African Art. Washington and London: Smithsonian Institution Press.

[16] Drewal, H. J. (1983). Art and Divination among the Yoruba: Design and myth. Africana Journal, 14. Retrieved from www.worldcat.org/art-and-divination-among-the-yoruba-d.

[17] Drewal, H. J. (1980).African Artistry: Technique and Aesthetics in Yoruba Sculpture. Atlanta: The High Museum of Art.

[18] Drewal, H. J., Abiodun, R.and John Pemberton III. (1991) Yoruba Art And Aesthetics Zurich: Rietberg Museum.

[19] Drewal, H. J., Pemberton III, J., \&Abiodun, R. (1989). Yoruba: Nine Centuries of African Art and Thought. Exhibition Catalogue. New York: Centre for African Art.

[20] Drewal, M. T., \& Drewal, H. J. (1983).An Ifa Diviner in Ijebuland. African Arts, 16 (2), retrieved from www.africabib.org/rec.php?RID=P00016341\&DB=p.

[21] Emmanuel, A. (2000). OdunIfa. Nigeria: West African Book Publishers Limited. Lagos Nigeria.

[22] George and Thompson, (1980) Yoruba Religion and Medicine in Ibadan. Ibadan University press, Nigeria.

[23] Idowu E. B., Olodumare God in Yoruba Belief (1962) London. Longman Green and Co. Ltd.

[24] Jordan, M. (2000). Art and Divination among Chokwe, Lunda, Luvale and Related Peoples of North West Zambia. In Pemberton III, J. (Ed.), Insights and Artistry in African Divination: Cross-Cultural Study Washington D. C. Smithsonian Institution Press.

[25] Layiwola, A. (2010). Benin 1879.com: Arts and the Restitution Question. An Exhibition Brochure. Indiana. University Post Office. Wy Art Edition.

[26] Meterowitz, L.R, (1946). Journal of International African Institute Vol. 14 N2. 
[27] Marshall W. Mont, (1980) African Art: DA CAPO Press Paperback Bloomington, Indiana.

[28] Olatunji, O. (1984). Features of Yoruba Oral Poetry. Ibadan. University press Limited, Ibadan.

[29] Shyllon, Y. A. and Odimayo, O. O. (2008). Ancient Tones and Columns. Exhibition catalogue, Lagos: National Gallery of Arts and Visual arts Society of Nigeria.

[30] Parrot, J. F. (1972). Introduction to African Arts of Kenya, Zaire and Nigeria. New York. Arco publishing Company, Inc.

[31] Permberton, J. (2007). African Arts and Rituals of Divination: a scholarly resource from Metropolitan Museum of Art. Retrieved from www.metmuseum.org/explore/ore/oracle/art

[32] Permberton, J (2004) Yoruba Carvers: past and present. An essay posted by David Zeamanek. Retrieved from www. Tribalartforum.org.

[33] Pogoson, O. I., \&Akande, A. O. (2011). Ifa Divination Tray from Isale Oyo: retrieved from wwwcea.revues.org

[34] Rowland, A. (1974). Ifa Art Objects: An Interpretation Based on Oral Traditions. In Yoruba Oral Tradition: Poetry in Music, Dance and Drama. Department of African languages and literatures, University of Ife.

[35] Sanda, A. (2012) Art In the Service of Religion; A Study of Ifa Divination System in Oyo. Unpublished M.A thesis, University of Lagos, Nigeria.

[36] Stainner, C.B. (1995) African Art in Transit. Britain, Cambridge University Press.

[37] The New International Illustrated Encuclopedia of Art. (1950). New York. Greystone Press.

[38] Werrner, Gillon. (1991) A Short History of African Art. Britain. Pengium Books Ltd.

[39] Wescott, Joan. (1958). Yoruba Art in German and Swiss Museums. Yoruba Historical Research Scheme. Ibadan University Press, Nigeria.

[40] Willet, Frank. (1993). African Art: An Introduction. New York. Thames \& Hudson.

[41] Witte H (1994) Ifa Divination Tray form Oshogbo and Ijebu Regions. In Abiodun R, D. 